\title{
Entrepreneurship education and sustainable development: mediating role of entrepreneurial skills
}

\author{
James Edomwonyi Edokpolor \\ Department of Education, Benson Idahosa University, Benin City, Nigeria
}

Education and sustainable development

Received 25 March 2020 Revised 28 May 2020 4 June 2020

15 August 2020

Accepted 5 September 2020

\begin{abstract}
Purpose - This study aims to examine the mediating role of entrepreneurial skills developed by undergraduates (ESDU) in the relationship between entrepreneurship education (EE) and the core values of sustainable development (CVSD).

Design/methodology/approach - This is a correlational study that used a structured questionnaire for quantitative data collection from 399 purposively selected Nigerian university undergraduates.

Findings - The results confirmed the statistically significant and positive mediating role of ESDU on the relationship between $\mathrm{EE}$ and the CVSD.

Originality/value - This study has contributed to the mediating role of ESDU in the relationship between $\mathrm{EE}$ and the CVSD. This interrelationship can further provide a better understanding or insights into how ESDU can help mediate the relationship between EE and the CVSD.
\end{abstract}

Keywords Mediating role, Sustainable development, Entrepreneurship education, Core values, Entrepreneurial skills, University undergraduates

Paper type Research paper

\section{Introduction}

The integration of entrepreneurship education (EE) into the university education curriculum in Nigeria was to equip undergraduates with skills to function well and contribute to society upon graduation (Davwet et al., 2019). This goal is reflected in the Nigerian universities' strategic plans to provide the chance for undergraduates to become entrepreneurs and lifetime learners. EE was introduced to equip undergraduates from various disciplines with entrepreneurial skills needed to possess life-sustaining essentials, be a person, and be free from social servanthood. The ability of undergraduates to possess life-sustaining essentials, be a person, and gain freedom are described in economic development literature as core values of sustainable development (CVSD) (Mensah, 2019).

To achieve the goal of EE, a Centre for Entrepreneurship Development was established in most Nigerian Universities, which implies that EE occupies a strategic position in most Nigerian universities. The goal of EE to promoting the CVSD through entrepreneurial skills

(C) James Edomwonyi Edokpolor. Published in Asia Pacific Journal of Innovation and Entrepreneurship. Published by Emerald Publishing Limited. This article is published under the Creative Commons Attribution (CC BY 4.0) licence. Anyone may reproduce, distribute, translate and create derivative works of this article (for both commercial and non-commercial purposes), subject to full attribution to the original publication and authors. The full terms of this licence maybe seen at $\mathrm{http} / / /$ creativecommons.org/licences/by/4.0/legalcode 
APJIE 14,3

developed by undergraduates (ESDU) can never be overemphasized. It is on this premise that the Federal Government of Nigeria through the National Universities Commission (NUC) mandated Nigerian universities to integrate EE into their curriculum to curb the increasing rates of social problems in the country.

Notably, the social problems that have engulfed most university graduates' in Nigeria are unemployment and poverty. For instance, studies have shown that the unemployment rate is still on the increase as of late, with examples being: $25.5 \%$ of young youths between ages of 15 and 35 years old were unemployed in the third quarter of 2017 and increased to $30.50 \%$ in the second quarter of 2018 , and $52.6 \%$ of young youths between ages of 15 and 34 years old were unemployed in the third quarter of 2017 and increased to $55.4 \%$ in the same quarter of 2018 (National Bureau of Statistics, 2018). An earlier study also reported that more than $70 \%$ of young youths were living in abject poverty; that is to say that these young youths are living below poverty line, while one-third are said to be surviving on less than one dollar a day (National Bureau of Statistics (NBS), 2012). Therefore, the high rates of unemployment and poverty suggested that graduates from numerous universities in the country possessed a low-level of entrepreneurial skills, which appear to hinder their opportunity to possess CVSD, such as, ability to lead a quality lifestyle, ability to be a person, and ability to be able to make choice. It, therefore, implies that the influence of EE in promoting CVSD has been widely challenged. To curb the increasing rates of unemployment and poverty in Nigeria, there is a need for major stakeholders (like, governments, NGOs, international donor agencies, and employers of labor) to collaboratively invest their resources both financial and otherwise on EE (Edokpolor and Owenvbiugie, 2017). For instance, the cooperation among major stakeholders may help in optimizing instructional resources to equip university undergraduates with entrepreneurial skills to achieve CVSD.

Concerning the high rates of unemployment and poverty, as exemplified above, the current study becomes important, as it would provide a better understanding of how ESDU mediates the relationship between EE and CVSD. Hence, the current study seeks to examine the mediating role of ESDU in the relationship between EE and CVSD. Therefore, the current study has provided a significant contribution to the literature in the following ways. The quest to examine the role of ESDU as a plausible mediator of the relationship between EE and CVSD, which has proved to attract limited attention from other researchers.

An attempt to fill this gap is a significant step in the current study. Early theorists (Schumpeter, 1934; Becker, 1975) and current researchers (Ekawarna and Kusmana, 2019; Wei et al., 2019) suggests that entrepreneurial skills could strengthen the interplay between $\mathrm{EE}$ and CVSD. In this context, EE has long been supported as a relevant factor for developing entrepreneurial skills and promoting CVSD. Therefore, this study aims at contributing to existing literature concerning the mediating role of ESDU in the relationship between EE and CVSD.

Despite the support of early theorists and current researchers on the role of entrepreneurial skills on the interplay between EE and CVSD, there are still gaps in the literature on how this interplay would hold in developing countries, like Nigeria (Hall et al., 2010). Some researchers ( $\mathrm{Li}$ and Wu, 2019; Ndofirepi, 2020) have examined the role of entrepreneurial skills in the interplay between $\mathrm{EE}$ and entrepreneurial intentions. None of these researchers examined the role of ESDU in the interplay between EE and CVSD. Moreover, there is still a gap in the literature on a conceptual model concerning how ESDU mediates the interplay between EE and CVSD. Hence, the present study aims to contribute to the literature concerning the role of ESDU in the interplay between EE and CVSD. 
Furthermore, the results of the study might provide new data that could ensure better ways for EE to equip undergraduates with the entrepreneurial skills to achieve CVSD.

\section{Literature review and hypotheses development}

\section{Entrepreneurship education and entrepreneurial skills development}

Edokpolor and Somorin (2017) remarked that EE cut across all academic disciplines, aiming to equip recipients with skills to create something new or include something new into an existing product to solve problems and discover business opportunities. Doğan (2015) opined that EE is an important instrument for encouraging entrepreneurial tasks because education provides the skills that students will use to start a business. Sulaiman and Wan-Fauziah (2013) saw EE as education designed to change the mind-set of students by equipping them with the skills to launch a business. This means that EE plays a key role in equipping university undergraduates with the skills to launch a business upon graduation. EE provides a practical opportunity for university undergraduates to develop entrepreneurial skills in a challenging learning environment.

The essence of EE is to develop entrepreneurial skills in individuals to successfully launch a business (Chhabra et al., 2020). Collectively, EE develops the skills that enable individuals to participate meaningfully in all aspects of life, create something valuable, and gain financial independence, or personal satisfaction, or both (Steenekamp, 2013). A key assumption of $\mathrm{EE}$ is that entrepreneurial skills can be developed among individuals (Sirelkhatim and Gangi, 2015) via a practical learning environment. In support of this claim, an existing study by Sanchez (2011) found that students' who participated in EE are more likely to start a business upon graduation due to a high level of entrepreneurial skills possessed by such students. Thus, the author hypothesized as follows:

H1. EE is a significant positive predictor of ESDU.

\section{Entrepreneurial skills and core values of sustainable development}

Edokpolor and Chukwuedo (2018) saw entrepreneurial skills as competencies required by students to start a business. Partnership for 21st Century Skills (2008) grouped entrepreneurial skills as core skills; life and career skills; learning and innovation skills; and information, media and technology skills. Global e-Schools and Communities Initiative (2013) noted that entrepreneurial skills are often classified among the non-cognitive skills. It described non-cognitive skills as socio-emotional traits and behaviors (also called "soft" skills). Entrepreneurial skills can be measured through items such as communication, creativity and innovation, teamwork and collaboration, critical thinking and problem solving, desirability and feasibility, ICT literacy, social and cross-cultural, learning and selfdirection, management and leadership, and flexibility and adaptability. Possessing these skills would provide opportunity for undergraduates to generate the income capacities to secure life-sustaining essentials, be a person, and make the right choice.

The UN (2016) has identified entrepreneurial skills as a key element for advancing social cohesion, lessening disparities and extending open doors for all individuals. The UN recognized entrepreneurial skills as a contributing element to social outcomes by catalyzing the advancement of productive capacities and fostering business creation that extends pool of opportunities to all individuals, with a chance to participate in and benefit from sustainable economic development.

There is a significant recognition that EE will transform graduates from employees to employers, and provide opportunity for them to key into the effort of the government to
Education and sustainable development 
APJIE 14,3

\section{2}

\section{Entrepreneurship education and core values of sustainable development}

Sustainability emerged from sustainable development, meaning development that meets the needs of the present without compromising the ability of future generations to meet their own needs (WCED, 1987). Development has been associated with diverse meanings, interpretations and theories from various scholars. It is understood as a certain process of advancing human well-being, self-esteem, and freedom (Todaro and Smith, 2011). Bringing sustainability and development together can be defined as a continuous expansion of an economy with the advancement of social, economic and political life of present and future generations. Therefore, sustainable development is not a constant or fixed state of harmony; rather, it is a lifetime process of evolution in which people take actions that leads to a development that meet the current needs without compromising the abilities of future generations to meet their own needs. It can be viewed as a persistent increase in economic growth, leading to economic competitiveness, high standard of living and self-reliance. It can be seen also as a development that permits future generations to access well-being, selfesteem and freedom.

Sen (1999) stated that individuals are not free if they cannot choose or are imprisoned by living on the margins of life-sustaining essentials without quality education or requisite skills. The UN (2016) stipulated that advancing human well-being, self-esteem and freedom, contribute to the sustainable development of nations. Meaning that advancing human wellbeing, self-esteem, and freedom are inherently important for social, economic, and environmental change, hence, $\mathrm{EE}$ is inevitable. It is also documented in the literature that $\mathrm{EE}$ is an important element for advancing the CVSD (Wu et al., 2017; Donkor et al., 2018). Research have also confirmed that there is a positive and significant relationship between $\mathrm{EE}$ and entrepreneurial intentions (Rauch and Hulsink, 2015), which would provide the opportunity to achieve human well-being, self-esteem, and freedom from the foregoing, one could assert that EE play a great role in advancing CVSD. Therefore, the author hypothesized as follows:

\section{H3. EE is a significant positive predictor of CVSD.}

\section{A study model}

The author of this study developed a research model (Figure 1) upon which the hypothetical propositions of all the study variables and mediation effect are based. The model described

Figure 1.

Conceptual framework of the study

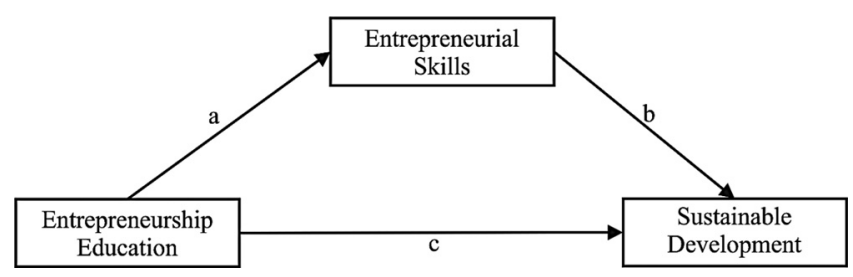


the role of ESDU in the relationship between $\mathrm{EE}$ and CVSD. The research model is a single mediation model that helps to describe the mediating role of ESDU in the relationship between EE and CVSD.

The UN (2016) stipulated that EE is an important measure for advancing CVSD, such as, human well-being, self-esteem, and freedom. The UN pointed out that the Goal 4 of sustainable development agenda is to ensure that all individuals have access to EE and lifelong learning and acquire entrepreneurial skills to function well and contribute to the society. This goal is hinged on the expectation that EE should make an optimum contribution to sustainable development by making entrepreneurial skills acquisition a requirement for all universities in Nigeria (Federal Republic of Nigeria (FRN), 2013). Therefore, EE aims at developing entrepreneurial skills, which is a driving force for the future achievement of human well-being, resilience and freedom. Kabir et al. (2017) found that EE provides the skills that will help individuals to change their mind-set from job searchers to job creators. They argued that focusing on developing enterprise skills via EE will play a key role in encouraging entrepreneurial start-ups that provide opportunities for advancing human well-being, self-esteem, and freedom. Hence, the author of this study hypothesized as follows:

H4. ESDU is a significant positive mediator of EE and CVSD.

\section{Research methodology}

Participants: a total of 399 university undergraduates participated in the study. These participants were from different faculties, e.g. faculty of arts and education, faculty of agriculture and agricultural technology, faculty of law, faculty of science, faculty of social and management sciences and faculty of engineering. Purposive sampling method was used to select the participants because they were defined groups of undergraduates who had previously participated in a university-wide EE program. The study was conducted at the time these groups of undergraduates were in their final year of the Bachelor's degree programs.

Measures: the author designed a questionnaire for data collection, consisting of demographic data of undergraduates' and questionnaire items. Demographic data of undergraduates consist of their gender, age, and faculty. Gender was represented as male $(187,53 \%)$ and female $(212,57 \%)$. Age was grouped as 20 to 25 years $(229,57 \%), 26$ to 30 years $(106,27 \%), 31$ to 35 years $(33,8 \%), 36$ to 40 years $(20,5 \%)$ and 41 years and above $(11,3 \%)$. Faculties were grouped as faculty of arts and education (96, 24.4\%), faculty of agriculture and agricultural technology $(04,1.0 \%)$, faculty of law $(56,14.0 \%)$, faculty of science $(86,21.6 \%)$, faculty of social and management sciences $(99,24.9 \%)$ and faculty of engineering $(58,14.5 \%)$.

Items 1 to 4 measure EE, items 5 to 14 measure ESDU, and items 15 to 17 measure CVSD. The instrument was a seven points Likert type questionnaire, ranging from $1=$ Strongly Disagree to $7=$ Strongly Agree. Perception of undergraduates was used to measure EE. A sample of questionnaire item for $\mathrm{EE}$ is: "EE aims at developing undergraduates' potential attributes that form the basis of entrepreneurial behaviour". A sample of questionnaire item for ESDU is: "undergraduates' need to develop new and useful skills to improve on existing products". A sample of questionnaire item for CVSD is: "undergraduates' need to be able to access basic human needs after graduation".

The reliability test was conducted using the Cronbach's alpha method to ascertain the internal consistency of the instrument. Coefficients alpha provides overall reliability for the instrument and confirms that the instrument can be administered with confidence to 
APJIE 14,3

\section{4}

Table 1.

Mean, standard deviations and correlation of the study variables measure $\mathrm{EE}(\alpha=0.910)$, ESDU ( $\alpha=0.903)$, and CVSD $(\alpha=0.914)$. Coefficients obtained meet the minimum value of 0.600 thresholds for adequate reliability measure on internal consistency as recommended (Creswell and Poth, 2018).

Data analyses. Data was analyzed via quantitative statistics (e.g. mean, standard deviations, correlation, and regression) using the IBM Statistical Package for Social Sciences (SPSS) 23.0 and PROCESS for SPSS. Correlation and regression statistics were used to analyze the relationships between and among the study variables (e.g. EE, ESDU and CVSD). A mediation analysis was used to determine the mediating role of ESDU in the relationship between $\mathrm{EE}$ and CVSD.

\section{Results}

The author conducted a preliminary data analysis to determine the need for a mediation analysis. For instance, when there is a significant relationship between the predictor variable and outcome variable, mediation analysis can be performed. This explanation guided the author while conducting the preliminary data analysis for the study. Therefore, the author used the mean, standard deviations, Cronbach's alpha, correlation, and regression for data analyses in the study. Table 1 shows that the relationship among the study variables is relatively positive. As the relationship among the study variables is relatively positive, it therefore authenticates the need to perform the mediation analysis proposed in the study.

Table 1 shows the correlation between the study variables. Table 1 also shows the mean responses of undergraduates', ranging from 19.05 to 64.79 and the standard deviations ranging from 1.112 to 5.208 . Table 1 shows that the relationship among studied variables ranged from 0.459 to 0.695 . Results depict that there are positive correlations between and among EE, ESDU, and CVSD.

$H 1$ to $H 3$ were tested using regression statistic. The results of the hypotheses are presented in Tables 2 and 3.

Table 2 shows that EE is a significant positive predictor of $\mathrm{ESDU}(\mathrm{F}=371.892, t=$ 19.285, $\beta=0.695, p<0.001)$. Adjusted R-square $(0.482)$ shows that $48.2 \%$ of variances in ESDU is determined by EE. Hence, the hypothesis proposed for the study is supported, implying that EE will help in developing entrepreneurial skills among undergraduates.

\begin{tabular}{llcccc}
\hline S/N & Variables & $M$ & $S D$ & 1 & 2 \\
\hline 1. & EE & 26.19 & 1.319 & & \\
2. & ESDU & 64.79 & 5.208 & $0.695^{* *}$ & \\
3. & CVSD & 19.05 & 1.112 & $0.459^{* *}$ & $0.653^{* *}$
\end{tabular}

Notes: $* * p<0.01 ; N=399, M=$ Mean, $S D=$ Standard Deviations, EE = Entrepreneurship Education, $\mathrm{ESDU}=$ Entrepreneurial Skills Developed by Undergraduates, CVSD $=$ Core Values of Sustainable Development
Summary of simple linear regression

\begin{tabular}{lllllll}
\hline Hypo. & Variables & $R^{2}$ & $F(397)$ & Beta & $t$ & $p$ \\
\hline$H 1$ & EE $\rightarrow$ ESDU & 0.484 & 371.892 & 0.695 & 19.285 & 0.000 \\
$H 2$ & ESDU $\rightarrow$ CVSD & 0.427 & 295.520 & 0.653 & 17.191 & 0.000 \\
$H 3$ & EE $\rightarrow$ CVSD & 0.211 & 106.223 & 0.459 & 10.306 & 0.000
\end{tabular}

Note: $p<0.001$ 
Table 2 also shows that ESDU is a significant positive predictor of CVSD ( $\mathrm{F}=295.520, t=$ $17.191, \beta=0.653, p<0.001)$. Adjusted $\mathrm{R}$-square $(0.425)$ shows that $42.5 \%$ of variances in the CVSD are determined by ESDU. Hence, the hypothesis proposed for the study is supported, implying that ESDU will help in advancing the CVSD. Table 2 further shows that $\mathrm{EE}$ is a significant positive predictor of CVSD ( $\mathrm{F}=106.223, t=10.306, \beta=0.459$, $p<0.001)$. Adjusted R-square (0.209) depicts that $20.9 \%$ of variances in the CVSD is determined by EE. Therefore, the hypothesis proposed for the study is supported, implying that EE will help in advancing the CVSD.

Table 3 shows that total effect of EE on CVSD is significant $(\beta=0.387, \mathrm{SE}=0.038, p<$ 0.001). Direct effect of EE on CVSD is not significant $(\beta=0.008, \mathrm{SE}=0.045, p>0.001)$. Indirect effect of $\mathrm{EE}$ on CVSD via ESDU is fully significant $(\beta=0.379, \mathrm{SE}=0.088, \mathrm{CI}=$ 0.188 to 0.531 ); implying that ESDU is a full mediator of the interplay between EE and CVSD. Hence, these results imply that $H 4$ is highly supported in the study.

\section{Discussion}

This study examined the mediating role of ESDU in the relationship between EE and CVSD. The study contributed not only to the study of EE, ESDU, and CVSD but also contributed the assumptions that support the mediating role of ESDU in the interplay between EE and CVSD. The author applied correlation, regression, and mediation analyses to examine the interplay between and among EE, ESDU and CVSD. $H 1$ shows that EE is a significant positive predictor of ESDU. This finding concurs with the view of Bae et al. (2014) that EE contributes to the wellspring of ESDU. Early researchers (Peterman and Kennedy, 2003) confirmed that EE significantly predicts student's feasibility and desirability of starting a business.

H2 shows that ESDU significantly predict CVSD. This finding agrees with self-efficacy theory postulated by Bandura (1977), that a link exists between self-perceptions of personal skills and performing certain tasks, including decisions to participate in the sustainable development agenda. The finding from $\mathrm{H} 2$ also agrees with the assumptions proposed by McGrath and Powell (2016) that entrepreneurial skills promotes sustainable development and meets the needs of the poor. H3 shows that EE significantly predict CVSD. This finding does not agree with the research of Omelogo (2016) who conducted a study on the relationship between $\mathrm{EE}$ and sustainable development, but found a negative relationship between EE and sustainable development in the Nigerian economy.

$H 4$ shows that the relationship between EE and CVSD is significantly mediated by ESDU. This finding support the assertion of UNESCO (2015) that EE will serve as the lynchpin upon which CVSD is to be built, whose success depends on individuals' acquisition of entrepreneurial skills to address social problems of nations. $H 4$ also agrees with the assertion of Peterman and Kennedy (2003) that EE enhance students'

\begin{tabular}{|c|c|c|c|c|}
\hline \multirow[b]{2}{*}{ Effects } & \multicolumn{3}{|c|}{$\mathrm{EE} \rightarrow \mathrm{ESDU} \rightarrow \mathrm{CVSD}$} & $95 \% \mathrm{CI}$ \\
\hline & $B$ & SE & LL & UL \\
\hline Total & $0.387 * * *$ & 0.038 & 0.313 & 0.461 \\
\hline Direct & 0.008 & 0.045 & -0.079 & 0.096 \\
\hline Indirect & 0.379 & 0.088 & 0.188 & 0.531 \\
\hline
\end{tabular}

Note: $* * * p<0.001$
Education and sustainable development 
APJIE 14,3

entrepreneurial skills, in turn, enhances students' perceptions of desire to participate in sustainable development agendas, such as engaging in decent employment. H4 agrees with the assertion of Audretsch and Caiazza (2016) that EE is a driving force for developing entrepreneurial skills as a means to achieving the CVSD. The assertion of Moberg et al. (2014) supported $H 4$ arguing that national development depends on entrepreneurial skills development and which is from EE. It implies that the essence of EE worldwide is to promote sustainable development, since it equips students' with entrepreneurial skills. Equipping students' with entrepreneurial skills would help to adapt to changing conditions and meet the needs of sustainable development.

\section{Conclusion}

The current study focused on the mediating role of ESDU in the relationship between EE and the CVSD, which is a relatively less-explored area of research inquiry in the entrepreneurship field, especially in the context of developing nations such as Nigeria. The study contributed to the existing literature by providing a mediation model to assess the mediating role of ESDU in the relationship between EE and CVSD. The study indicated that EE and ESDU are the two major antecedents of CVSD. Therefore, the findings of the study provide some practical implications for governments, NGOs, parents, and employers of labour. If these stakeholders collaboratively invest their resources both financially and otherwise into EE, it will help in providing the practical learning environment that will equip undergraduates with entrepreneurial skills to possess the CVSD. As such, EE should be carefully implemented for university undergraduates to acquire entrepreneurial skills to possess the CVSD.

Despite the contributions of this present study to the existing literature, some limitations were spotted out. However, the study focused on entrepreneurial skills, not entire 21stcentury skills, as entrepreneurial skills are found to be a significant mediator of the relationship between EE and CVSD. The study was conducted via a correlational approach and as such, causal inference need not to be made in the study. Therefore, longitudinal and experimental procedures are recommended to explain the rigorous process of advancing the CVSD. If not, then what are the skills that could significantly and positively mediate the relationship between $\mathrm{EE}$ and $\mathrm{CVSD}$ ?

The participants were purposively drawn from universities in the South Senatorial District of Nigeria; therefore, caution needs to be exercised in generalizing the findings of the study. As such, future research should focus on using the proportional sampling procedure by covering broader Senatorial Districts (such as Edo Central and Edo North Senatorial Districts of Nigeria), to provide more balanced results from all the universities in the region. The participants are also homogenous, meaning that undergraduates only were used in the study; therefore, caution needs to be exercised in generalizing the findings of the study, especially to students in other higher academic institutions. As such, the undergraduates were used in the study because they are the best individuals to provide a useful opinion on $\mathrm{EE}$, which aimed at equipping them with entrepreneurial skills to advancing the CVSD. Hence, there is need to embark on further studies that includes students from other higher academic institutions. In addition, the perception of undergraduates was used to measure $\mathrm{EE}$, which does not give the true picture of students' exposure to the program, rather it only determines what it ought to be but not what it is. Hence, future studies need to accommodate the area that measure the students exposure to EE. In addition, caution should be exercised in generalizing the findings because of the social desirability of the items (Podsakoff $e t$ al., 2003), since the exposure of undergraduates to EE program were not strictly measured; rather their perception of the program were measured. In addition, as the study was 
conducted in Nigeria, caution needs to be exercised in generalizing the findings to other countries. More so, future studies should cover other developing nations to provide balanced results.

With regards to the findings of the study, the author concludes that the integration of EE into the university education curriculum at the national level in Nigeria is a welcome development, since it aimed to equipping undergraduates with the entrepreneurial skills for achieving the CVSD (e.g. well-being, self-esteem, and freedom). Despite the findings, the author still anticipates that the study will stimulate more rigorous studies that would incorporates EE, ESDU, and CVSD in other higher academic institutions (e.g. college of education, polytechnic, or innovation enterprise institution) to determine whether the study will be consistent with the results of this present study.

\section{References}

Audretsch, D.B. and Caiazza, R. (2016), "Technology transfer and entrepreneurship: cross-national analysis", Journal of Technology Transfer, Vol. 41 No. 6, pp. 1247-1259.

Bae, T., Qian, S., Miao, C. and Fiet, J. (2014), “The relationship between entrepreneurship education and entrepreneurial intentions: a meta-analytic review", Entrepreneurship Theory and Practice, Vol. 38 No. 2, pp. 217-254.

Bandura, A. (1977), "Self-efficacy: toward a unifying theory of behavioral change", Psychological Review, Vol. 84 No. 2, pp. 191-215.

Becker, G. (1975), Human Capital, Columbia University Press, New York, NY.

Chhabra, S., Raghunathan, R. and Rao, N.V.M. (2020), "The antecedents of entrepreneurial intention among women entrepreneurs in India", Asia Pacific Journal of Innovation and Entrepreneurship, Vol. 14 No. 1, pp. 76-9210.1108/APJIE-06-2019-0034.

Creswell, J.W. and Poth, C.N. (2018), Qualitative Inquiry and Research Design: Choosing among Five Approaches, Sage Publications, Thousand Oaks, CA.

Davwet, H.M., Damar, D.N., Goyit, M.G. and Kajang, Y.G. (2019), "Evaluation of the implementation of undergraduate general studies entrepreneurship curriculum in federal universities in NorthCentral geo-political zone, Nigeria”, Creative Education, Vol. 10 No. 6, pp. 1163-117910.4236/ ce.2019.106088.

Doğan, E. (2015), "The effect of entrepreneurship education on entrepreneurial intentions of university students in Turkey", Ekonometri ve İstatistik Sayl, Vol. 23 No. 1, pp. 79-93.

Donkor, J., Donkor, G.N.A. and Kwarteng, C.K. (2018), "Strategic planning and performance of SMEs in Ghana: the moderating effect of market dynamism”, Asia Pacific Journal of Innovation and Entrepreneurship, Vol. 12 No. 1, pp. 62-76.

Edokpolor, E.J. and Chukwuedo, S.O. (2018), “Technical and vocational education and training students' lifelong-career specific human capital: gender consideration for sustainable development", International Journal of Gender Studies and Research, Vol. 6 No. 1, pp. 51-61.

Edokpolor, J.E. and Owenvbiugie, R.O. (2017), "Technical and vocational education and training skills: an antidote for job creation and sustainable development of the Nigerian economy", Problems of Education in the 21st Century, Vol. 75 No. 6, pp. 535-549.

Edokpolor, J.E. and Somorin, K. (2017), "Entrepreneurship education programme and its influence in developing entrepreneurship key competencies among undergraduate students", Problems of Education in the 21st Century, Vol. 75 No. 2, pp. 144-156.

Ekawarna, S. and Kusmana, A. (2019), "The analysis of the effect of entrepreneurship education, perceived desirability, and entrepreneurial self-efficacy on university students' entrepreneurial intention", Universal Journal of Educational Research, Vol. 7 No. 11, pp. 2507-2518.

\section{Education and sustainable development}

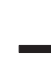


APJIE 14,3

Federal Republic of Nigeria (FRN) (2013), National Policy on Education, Educational Research and Development Council (NERDC) Press, Abuja, Nigeria.

Global e-Schools and Communities Initiative (2013), Development of 21st-Century Skills for Innovation and Enterprise: Exploring the Role of Informal Learning Environments in the Development of Skills and Aptitudes for the Digital Creative Media Industries, University of Nairobi, School of Computing and Informatics, Nairobi, Kenya.

Hall, J.K., Daneke, G.A. and Lenox, M.J. (2010), "Sustainable development and entrepreneurship: past contributions and future directions", Journal of Business Venturing, Vol. 25 No. 5, pp. 439-448.

Kabir, S.M., Haque, A. and Sarwar, A. (2017), "Factors affecting the intention to become an entrepreneur: a study from Bangladeshi business graduates' perspective”, International Journal of Engineering and Information Systems, Vol. 1 No. 6, pp. 10-19.

Li, L. and Wu, D. (2019), "Entrepreneurial education and students' entrepreneurial intention: does team cooperation matter?", Journal of Global Entrepreneurship Research, Vol. 9 No. 1, pp. 1-13.

McGrath, S. and Powell, L. (2016), "Skills for sustainable development: transforming vocational education and training beyond 2015”, International Journal of Educational Development, Vol. 50 No. C, pp. 12-19.

Mensah, J. (2019), "Sustainable development: meaning, history, principles, pillars, and implications for human action: a literature review", Cogent Social Sciences, Vol. 5 No. 1, pp. 1-21.

Moberg, K., Vestergaard, L., Fayolle, A., Redford, D., Cooney, T., Singer, S. and Filip, D. (2014), How to Assess and Evaluate the Influence of Entrepreneurship Education: A Report of the ASTEE Project with a User Guide to the Tools. ASTEE Project, The Danish Foundation For Entrepreneurship - Young Entrepreneurs, Ireland.

National Bureau of Statistics (NBS) (2012), The Nigeria Poverty Profile 2010 Report. Press Briefing by the Statistician-General of the Federation and Chief Executive Officer, National Bureau of Statistics, held at the Conference Room, NBS Headquarters, Central Business District, Abuja, Nigeria.

Ndofirepi, T.M. (2020), "Relationship between entrepreneurship education and entrepreneurial goal intentions: psychological traits as mediators", Journal of Innovation and Entrepreneurship, Vol. 9 No. 1, pp. 1-20.

Nwambam, A.S., Nnennaya, O.O. and Nwankpu, I.S. (2018), "Evaluating the entrepreneurship education programme in Nigerian universities for sustainable development", Journal of Entrepreneurship Education, Vol. 21 No. 1, pp. 1-13.

Omelogo, U.F. (2016), "Effect of entrepreneurship education on sustainable development in emerging economies", EPRA International Journal of Economic and Business Review, Vol. 4 No. 6, pp. 23-36.

Osoba, A.M. and Tella, S.A. (2017), "Human capital variables and economic growth in Nigeria: an interactive effect", EuroEconomica, Vol. 36 No. 1, pp. 405-415.

Partnership for 21st Century Skills (2008), 21st Century Skills, Education and Competitiveness: A Resource and Policy Guide. Tucson, AZ.

Peterman, N.E. and Kennedy, J. (2003), "Enterprise education: influencing students' perceptions of entrepreneurship”, Entrepreneurship Theory and Practice, Vol. 28 No. 2, pp. 129-144.

Podsakoff, P.M., MacKenzie, S.B., Lee, J. and Podsakoff, N.P. (2003), "Common method biases in behavioral research: a critical review of the literature and recommended remedies", Journal of Applied Psychology, Vol. 88 No. 5, pp. 879-903.

Rauch, A. and Hulsink, W. (2015), "Putting entrepreneurship education where the intention to act lies: an investigation into the impact of entrepreneurship education on entrepreneurial behaviour", Academy of Management Learning and Education, Vol. 14 No. 2, pp. 187-204.

Schumpeter, J.A. (1934), The Theory of Economic Development, Harvard University Press, Cambridge.

Sen, A. (1999), Development as Freedom, Oxford University Press, Oxford. 
Sirelkhatim, F. and Gangi, Y. (2015), "Entrepreneurship education: a systematic literature review of curricula contents and teaching methods", Cogent Business and Management, Vol. 2 No. 1, pp. 1-11.

Steenekamp, A.G. (2013), "An assessment of the impact of entrepreneurship training on the youth in South Africa", PhD Full Dissertation", North-West University, South Africa.

Sulaiman, M.L. and Wan-Fauziah, W.Y. (2013), "The perception of students towards entrepreneurship course: an empirical study of Nigerian polytechnics students", Paper Proceedings of the 2013 Technology Management, Business, and Entrepreneurship (TMBE) 2nd International Conference. Held at Mahkota Hotel Melaka, Malaysia, pp. 227-240.

Education and sustainable development

Todaro, M.P. and Smith, S.C. (2011), Economic Development, Pearson Education, Harlow, England.

UNESCO (2015), Education for All 2000-2015: Achievements and Challenges; EFA Global Monitoring Report, 2015, UNESCO Publishing, Paris, France.

United Nations (2016), Entrepreneurship for Sustainable Development; Resolution Adopted by the General Assembly, United Nations Publications, New York, NY.

Wei, X., Liu, X. and Sha, J. (2019), "How does entrepreneurship education influence students' innovation? Testing on the multiple mediation model", Frontiers in Psychology, Vol. 10 No. 1, pp. 1-10.

World Commission on Environment and Development (1987), Our Common Future: Report of the 1987 World Commission on Environment and Development, United Nations, Oslo, Norway.

Wu, P., Yao, X. and Muhammad, S. (2017), "The effect of female participation in top management teams on the growth performance of small and medium-sized enterprises (SMEs): evidence from a panel-data analysis in Chinese-listed SMEs", Asia Pacific Journal of Innovation and Entrepreneurship, Vol. 11 No. 1, pp. 108-119.

\section{Further reading}

Ali, M., Egbetokun, A. and Memon, M.H. (2017), "Human capital, social capabilities, and economic growth", Economies, Vol. 6 No. 1, pp. 1-18.

Ekperiware, M.C., Olatayo, T.O. and Egbetokun, A. (2017), "Human capital and sustainable development in Nigeria: how can economic growth suffice environmental degradation?", Economics Discussion papers No. 2017-29, Kiel Institute for the World Economy, Kiel, Germany.

Krueger, N.F., Jr and Brazeal, D.V. (1994), "Entrepreneurial potential and potential entrepreneurs", Entrepreneurship Theory and Practice, Vol. 18 No. 3, pp. 91-104.

National Bureau of Statistics (NBS) (2018), Labour Force Statistics Volume I: Unemployment and Underemployment Report. Abuja, Nigeria.

Sánchez, J.C. (2011), "University training for entrepreneurial competencies: its impact on intention of venture creation", The International Entrepreneurship and Management Journal, Vol. 7 No. 2, pp. 239-254.

\section{Corresponding author}

James Edomwonyi Edokpolor can be contacted at: jedokpolor@biu.edu.ng

For instructions on how to order reprints of this article, please visit our website:

www.emeraldgrouppublishing.com/licensing/reprints.htm

Or contact us for further details: permissions@emeraldinsight.com 